\title{
Analysis of fluoride concentration in commercial bottled waters
}

\author{
Análise da concentração de flúor em águas comercializadas
}

Davi Oliveira BIZERRIL ${ }^{1}$

Janaína Rocha de Sousa ALMEIDA'

Kátia de Góis Holanda SALDANHA ${ }^{1}$

Ronaldo Emilio CABRAL FILHO'

Maria Eneide Leitão de ALMEIDA ${ }^{1}$

\section{ABSTRACT}

Objective

Evaluate fluoride concentration in $500 \mathrm{~m} /$ commercial brands of bottled water and compare it to the amount printed on the label.

\section{Methods}

A descriptive, cross-sectional epidemiological study was conducted. Samples of nine different commercial brands of 500m/ bottled water were collected at authorized distribution points in the city of Fortaleza, CE, Brazil, in 2013. Fluoride concentration was determined in duplicate using a fluoride ion-selective electrode. The results were obtained from linear regression of the calibration curve.

\section{Results}

Fluoride concentrations ranged between 0.07 and 0.63 ppm F- or mg F/L. There were significant differences between the values printed on the labels and those found in the analysis. The fluoride concentration levels determined were not in compliance with the recommended levels by the National Health Surveillance Agency.

\section{Conclusions}

The results obtained confirm the need for more careful monitoring of fluoride levels in bottled water and closer sanitary inspections.

Indexing terms: Bottled water. Fluoridation. Fluorine compounds. Health surveillance.

\section{RESUMO}

\section{Objetivo}

Avaliar a concentração de flúor na água engarrafada comercializada, com padrão de apresentação de 500 ml, comparando-a aos valores impressos no rótulo da embalagem.

\section{Métodos}

Estudo epidemiológico, descritivo e transversal. Foram coletadas amostras das nove marcas disponíveis, na forma de apresentação de 500 ml, nos pontos de distribuição autorizados do município de Fortaleza, em 2013. A concentração de flúor foi determinada por análise em duplicata, utilizando o eletrodo íon-específico para fluoretos. Os resultados de concentração de flúor foram obtidos através da regressão linear da curva de calibração.

\section{Resultados}

A concentração de flúor variou entre 0,07 e 0,63 ppm de flúor por mg/l, com diferenças significantes entre os valores estipulados nos rótulos e os encontrados com a análise, além de apresentar a concentração foram do padrão preconizado pela vigilância sanitária.

\section{Conclusões}

Os resultados reforçam a necessidade de um controle dos níveis de flúor em águas engarrafadas, além de uma maior fiscalização por parte da vigilância sanitária.

Termos de indexação: Água engarrafada. Fluoretação. Compostos de flúor. Vigilância sanitária.

\section{INTRODUCTION}

In the last decades of the 20th century, the use of fluoride have exerted great impact on the control of dental caries even though, technically, its use alone does not prevent cavities but rather controls the rate at which they develop. Fluoride can be ingested through water although there are other fluoride sources including toothpastes, gels, mouth rinses, juices and other beverages, and food and infant formula prepared with fluoridated water. Low-level fluoride

\footnotetext{
${ }^{1}$ Universidade Federal do Ceará, Faculdade de Odontologia, Departamento de Clínica Odontologia. Rua Monsenhor Furtado, s/n., Rodolfo Teófilo, 60430-350, Fortaleza, CE, Brasil. Correspondência para/ Correspondence to: DO BIZERRIL. E-mail: <davibizerri@gmail.com>.
} 
exposure does not provide adequate protection against dental caries, and multiple sources of fluoride exposure are associated to greater chance for developing dental fluorosis. Therefore, the safe and adequate intake of fluoride is recommended, especially in the form of fluoridated water from public water supply and bottled mineral water ${ }^{1-3}$.

Mineral water comes from natural sources or can be collected artificially from different sources; it can be differentiated from tap water due to its chemical, physical, or physicochemical properties and medicinal qualities ${ }^{4}$. The consumption of bottled mineral water in Brazil has grown continuously, especially in the Southeast and Northeast regions, with an increasing number of bottled water brands available in the market. Consumers, in general, believe that this source of water has fewer impurities, and therefore there is reduced risk of contamination with pathogens that cause waterborne diseases; thus, it is supposedly healthier and more suitable for daily intake, especially for children ${ }^{1,5-9}$.

since mineral water can have residual fluoride concentration, its consumption by children can lead to dental fluorosis if the concentration of ionic fluoride is not adequate ${ }^{1,7}$. However, when this type of water has low levels of fluoride and is not combined with other forms of fluoride intake, such as from fluoride toothpastes, there is an increased chance of tooth decay. Nevertheless, few studies have addressed the quality of mineral bottled waters in terms of fluoride content.

According to the guidelines established by the National Health Surveillance Agency (ANVISA), ResolutionRDC n. 54, June $15^{\text {th }}, 2000$, bottled mineral water must contain fluoride, and information about the fluoride content must be clearly visible on the label. When fluoride concentration is higher than $1 \mathrm{ppm} \mathrm{F}$, it is not suitable for regular consumption by infants or children aged $\leq 7$; when it is higher than 2 ppm F-, it is not recommended for human consumption. Furthermore, fluoride concentration must range between 0.6 to $1.7 \mathrm{ppm} \mathrm{F}^{-10}$.

Due to the increase in the consumption of fluoridated bottled water, the concern about the adequate fluoride content of bottled mineral water, the considerable variety of brands available in the market, and the lack of studies on this topic in the North and Northeast regions of Brazil, it is advisable to evaluate bottled waters sold in state capitals in the Northeastern region, such as Fortaleza, the state capital of Ceará (CE).

The objective of this study was to evaluate the fluoride concentration of bottled mineral waters sold in the city of Fortaleza (CE), verifying the compliance with the criteria established by ANVISA (Resolution-RDC n. 54, June $\left.15^{\text {th }}, 2000\right)$ and with the information printed on the labels of the products studied.

\section{METHODS}

A descriptive, cross-sectional epidemiological study was carried out. The laboratory tests were conducted at the laboratories of the Graduate Program in Dentistry, Federal University of Ceará (UFC).

This sample studied comprised $500 \mathrm{ml}$ mineral bottled water brands sold in Fortaleza and belonging to the National Union of Mineral Water, Beer, and other Beverage Manufacturers in the State of Ceará (SINDBEBIDAS/CE); totaling 36 affiliates.

Sample selection was made based on a list of authorized manufacturers provided by the union (SINDBEBIDAS/CE), resulting in a sample composed of nine different bottled water brands. They were chosen according to the inclusion criteria for this study. The samples were collected between May and June 2013.

Only $500 \mathrm{ml}$ plastic water bottles were collected and evaluated. The waters were obtained at distribution points authorized by the union (SINDBEBIDAS/CE), where drinking water (including $500 \mathrm{ml}$ bottles) and other beverages are sold for human consumption.

The sample inclusion criteria included: being acquired before the expiration date established by the manufacturer and being from different production batches. Exclusion criteria included: bottled waters that did not came from the points of distribution, for example, those sold by street vendors and at informal settlements and different bottle sizes (other than 500ml).

Each bottled water sample was analyzed in duplicate and was not diluted. The samples of each brand were counted blindly, and those from different batches were identified.

Fluoride content readings were taken in millivolt $(\mathrm{mV})$ in duplicate using a fluoride ion-selective electrode (Orion 9609) connected to an ion analyzer (Orion EA 940, Thermo ${ }^{\circledR}$ Electron Corporation MA, USA). The measurements obtained were converted to ppm (parts per million).

The instrument calibration was performed using fluoride standard solutions ranging in concentration from 0.05 to 2.0 ppm F- (prepared from 100.0 ppm F- 940907 Orion fluoride standard) and TISAB II (Total lonic Strength Adjustor Buffer), a $1 \mathrm{M}$ acetate buffer, pH 5.0, $1.0 \mathrm{M} \mathrm{NaCl}$, and $0.4 \%$ CDTA (1,2-Cyclohexylenedinitrilotetraacetic acid). The fluoride standard solutions and the TISAB I| solution were used in the ratio 1:1 ( $/ / \mathrm{V})$. The standards were chosen based on the desired fluoride concentration in the samples. 
The average reproducibility of the measurements (in duplicate) was $98 \%$. In addition, the validation of results was verified with extra readings of $50 \%$ of the samples (intraexaminer reliability), with average reproducibility of $93.5 \%$.

The samples were analyzed after calibration of the ion-selective electrode coupled with the ion analyzer. The readings of the standards and the samples were performed under stirring using magnetic stirrer (MARTE) and magnet stir bars for one minute for all samples.

Fluoride concentration in the samples was determined according to the equipment operating procedure, and the accuracy of the results was evaluated using solutions of known concentration (test solutions), added every 10 readings. There was no difference greater than $3 \%$.

The data obtained in $\mathrm{mV}$ were inserted into a properly calibrated Excel spreadsheet for analysis and comparison of the results. The fluoride concentration results were obtained from linear regression of the calibration curve.

The present study did not involve, directly or indirectly, the participation of human subjects, but it was conducted in compliance with the ethical principles of the Declaration of Helsinki (2000). The research methodology involved only the analysis of fluoride concentration in bottled mineral waters. Respecting the confidential nature of the information used, the brand identities were not revealed; each sample was assigned a code number.

\section{RESULTS}

Eighteen samples were collected from nine different brands of $500 \mathrm{ml}$ plastic bottled mineral water. Among the brands evaluated, brand \# 2 had the most negative readings (different production batches) indicating higher fluoride content, as shown in Table 1.

Table 1. Readings $(\mathrm{mV})$ of fluoride content in the participating brands Fortaleza (CE), 2013

\begin{tabular}{lcc}
\hline Brand \# & $\begin{array}{c}\text { Reading } \\
(\mathbf{m V}) \\
\text { BATCH A }\end{array}$ & $\begin{array}{c}\text { Reading }(\mathbf{m V}) \\
\text { BATCH B }\end{array}$ \\
\hline Brand 1 & 54.3 & 55.1 \\
Brand 2 & -6.1 & -6.7 \\
Brand 3 & 42.0 & 55.8 \\
Brand 4 & 35.2 & 70.6 \\
Brand 5 & 52.6 & 47.5 \\
Brand 6 & 43.8 & 42.9 \\
Brand 7 & 45.0 & 44.1 \\
Brand 8 & 11.9 & 11.6 \\
Brand 9 & 40.5 & 43.4 \\
\hline
\end{tabular}

The fluoride concentration in the water samples ranged between 0.07 and 0.63 ppm F- or $\mathrm{mg} F / L$, among which, $88.8 \%$ had fluoride levels below (under-fluoridated) those recommended by ANVISA, which establishes the range 0.6-1.7 ppm $\mathrm{F}^{-}$as an acceptable concentration for fluoridated water. Only brand \# 2 was within the recommended levels for bottled mineral water, according to ANVISA $^{10}$ (Table 2).

Table 2. Average fluoride content (ppm F-) and water classification according to ANVISA. Fortaleza (CE), 2013.

\begin{tabular}{ccc}
\hline Brand \# & $\begin{array}{c}\text { (ppm F-) Average } \\
\text { fluoride content }\end{array}$ & $\begin{array}{c}\mathbf{0 . 6 - 1 . 7} \text { (ppm F-) classification } \\
\text { by ANVISA }\end{array}$ \\
\hline Brand 1 & 0.07 & Under-fluoridated \\
Brand 2 & 0.63 & Fluoridated \\
Brand 3 & 0.09 & Under-fluoridated \\
Brand 4 & 0.09 & Under-fluoridated \\
Brand 5 & 0.09 & Under-fluoridated \\
Brand 6 & 0.11 & Under-fluoridated \\
Brand 7 & 0.11 & Under-fluoridated \\
Brand 8 & 0.33 & Under-fluoridated \\
Brand 9 & 0.12 & Under-fluoridated \\
\hline
\end{tabular}

As for the fluoride content printed on the labels of the bottled mineral waters evaluated, the results show that the fluoride concentration was below the manufacturers' label level in five brands (55.55\%) and above it in three brands (33.33\%); only in one brand (11. 11\%), it corresponded to the value printed on the label (table 3 ).

Table 3. Fluoride concentration (ppm F-) printed on the labels of the bottled mineral waters evaluated, average fluoride concentration (ppm $\mathrm{F}^{-}$), and classification according to the labeled concentration. Fortaleza (CE), 2013.

\begin{tabular}{cccc}
\hline Brand \# & $\begin{array}{c}\text { (ppm F-) } \\
\text { Fluoride } \\
\text { concentration } \\
\text { printed on the } \\
\text { label }\end{array}$ & $\begin{array}{c}\text { (ppm F-) } \\
\text { Average } \\
\text { fluoride } \\
\text { concentration }\end{array}$ & $\begin{array}{c}\text { Classification } \\
\text { according to } \\
\text { the labeled } \\
\text { concentration }\end{array}$ \\
\hline Brand 1 & 0.07 & 0.07 & Same \\
Brand 2 & 0.48 & 0.63 & Below \\
Brand 3 & 0.03 & 0.09 & Below \\
Brand 4 & 0.05 & 0.09 & Below \\
Brand 5 & 0.03 & 0.09 & Below \\
Brand 6 & 0.05 & 0.11 & Above \\
Brand 7 & 0.03 & 0.11 & Above \\
Brand 8 & 0.75 & 0.33 & Below \\
Brand 9 & 0.03 & 0.12 & Above \\
\hline
\end{tabular}




\section{DISCUSSION}

The increased consumption of bottled mineral water, mainly in the tropical area of the country, either as an alternative or as a supplement to the public water supply, can affect the safety and effectiveness of fluoridation thus posing risk to human health ${ }^{1,11-15}$. Bottled mineral water is one of the sources of ingested fluoride and is considered a health promotion strategy, especially in terms of formation of dental tissues.

Among the nine brands evaluated, brand \# 2 had the most negative $\mathrm{mV}$ reading, which means the highest fluoride content. This indicates that only one of the participant brands was within the fluoride concentration levels recommended by public health surveillance. Thus, it has become a public health concern in terms of the low fluoride content in most of the waters investigated. The fluoride concentration values found varied significantly within the range $0.07-0.63 \mathrm{ppm} \mathrm{F-or} \mathrm{mg} F / L$, which is similar to the findings of Brandão \& Valsecki', Ramires et al. ${ }^{14}$ and Grec et al. ${ }^{15}$.

Corroborating the results reported by Ramires et al. ${ }^{14}$, there was no significant variations in fluoride concentration in the same brand, as seen in brands \# 3 and \# 4. However, in different batches, there were differences in the fluoride content in the same brand. This may be due to a number of reasons: for example, poor monitoring and supervision of addition of minerals during bottling; improper handling and storage of the product, varying ambient temperature, among others.

According to the regulations of fluoride amount in mineral water, (Resolution 54/2000 ${ }^{10}$ ), in order for water to be considered fluoridated, its fluoride concentration must be within the range 0.6-1.7 ppm F- Cury ${ }^{3}$ argued that the optimum fluoride concentration in mineral water should range between 0.6 and $0.8 \mathrm{ppm} \mathrm{F-}$, values that should be followed by bottled mineral water manufacturers, who, based on the fluoride appeal, often classify their product as fluoridated water, when, in fact, the fluoride concentration is not enough to have a preventive effect against dental caries ${ }^{5,9}$. Moreover, it can be seen in Table 2 that only brand \# 2 is in compliance with the limits recommended by ANVISA. This fact requires greater attention to the quality of these products since the content of additives, such as fluoride, is not within the adequate amount for human consumption. Studying the external control of fluoridation of water supplies in Brazilian municipalities, Catani et al. ${ }^{16}$ found that only $40 \%$ of these waters did not follow health surveillance recommendations.
The results obtained in the present study are significantly different from those reported by Sayed et al. ${ }^{17}$, who conducted a study in the city of Ponta Grossa (PR) and found that all brands evaluated had acceptable fluoride concentration levels and were thus safe for human consumption. However, similar to the findings of the present study, these authors found fluoride concentrations different from those listed on the labels.

With regard to the quantitative values printed on the labels of the participant brands, unlike the findings of Brandão \& Valsecki ${ }^{1}$ and Grec et al. ${ }^{15}$, all products evaluated listed the amount of fluoride on the label although the majority (55.55\%) had levels below the level specified, as shown in Table 3.

Investigating the fluoride content in bottled waters sold in the city of Pelotas (RS), Carvalho et al. ${ }^{18}$ found fluoride contents different from those listed on the labels of all the mineral waters evaluated. Additionally, some of the brands did not list the amount of fluoride on the label, and four of them had fluoride levels above that specified and thus could potentially cause dental fluorosis if consumed regularly by children while the teeth are being formed. The results of the present study corroborate those found by Grec et al..$^{15}$ in a study conducted in São Paulo (SP), in which the fluoride concentration varied significantly, with values above and/or below the set limits and different from those listed on the labels.

Franco \& Maltz ${ }^{19}$ and Villena et al. ${ }^{9}$ investigated bottled mineral waters sold in Brazil and found high fluoride concentrations not listed on the labels and low concentrations in fluoridated water. In 2004, Ramires et al. ${ }^{14}$ conducted a study in the municipality of Bauru (SP) and also found great differences between the fluoride measured concentrations and those listed on the labels, as well as concentrations lower than those recommended by the National Health Surveillance Agency.

Similar to what was reported by Ferreira et al. ${ }^{20}$, the present study has also identified poor monitoring and control of fluoride levels in water in different regions in the country, especially in spring sources. This fact indicates the need for consolidation and strengthening of community participation in addition to agreements with recognized regulatory and supervisory authorities and agencies.

Carvalho et al. ${ }^{6}$ carried out a study in the state of Espírito Santo, Brazil, and showed that epidemiological data on oral health and diseases, such as the DMFT (decayed, missing, and filled teeth), CPO-D in Portuguese, are influenced by the presence of fluoride in drinking water and that supervision and guidance are key factors for the proper use of fluoride products and reap their benefits 
to prevent and control dental caries with minimal risk of producing dental fluorosis.

\section{CONCLUSION}

Carried out in Fortaleza (CE), the present study identified differences between the fluoride levels listed on the label of bottled waters and those obtained in laboratory analysis; an irregularity that can induce people to consume mineral water in order to increase (or not) their dietary fluoride intake.

Similarly, in addition to the inaccurate information on the labels of the bottled waters investigated, the results obtained showed non-compliance with recommended fluoride levels. Therefore, it indicates the need for the formulation and adoption of strategies by regulatory and supervisory authorities and agencies and more careful and regular monitoring of the fluoride levels in bottled water spring sources. Moreover, in

\section{REFERENCES}

1. Brandão IMG, Valsecki A. Análise da concentração de flúor em águas minerais na região de Araraquara, Brasil. Rev Panam Salud Publica. 1998;4(4):238-42. doi: 10.1590/S102049891998001000003

2. Brasil. Ministério da Saúde. Guia de recomendações para o uso de fluoretos no Brasil. Brasília: Ministério da Saúde; 2009 [citado 2013 Maio 15]. Disponível em: <http://cfo.org.br/wp-content uploads/2010/02/livro_guia_fluoretos.pdf>.

3. Cury JA. Uso do flúor e controle da cárie como doença. In: Baratieri LN, Monteiro Júnior S, Andrada MAC, Vieira LCC, Ritter AV, Cardoso AC, et al. Odontologia restauradora: fundamentos e possibilidades. São Paulo: Santos; 2001. p. 33-68.

4. Brasil. Departamento Nacional de Produção Mineral. DecretoLei $n^{\circ} 7.841$, de 8 de agosto 1945. Dispõe sobre a Disciplina a utilização das águas minerais e potáveis de mesa regidas pelo Código de Águas Minerais (decreto-lei n 7.841 de 08 de agosto de 1945) como ingrediente no preparo de bebidas em geral. [online]. Diário Oficial da União, Brasília (DF); 2003 [citado 2013 maio 15]. Disponível em: <http://www.dnpm.gov.br/conteudo. asp? IDSecao=67\&IDPagina $=84 \& \mid$ L Legislacao $=3>$

5. Bastos JRM, Buzalaf MR, Levy FM, Ribeiro TT, Mazzone FHR. Concentração de flúor em água mineral engarrafada e de fontes naturais das cidades de Lindóia, Águas de Lindóia e Serra Negra, Brasil. RFO UPF. 2001;6(1):15-9.

6. Carvalho RB, Medeiros UV, Santos KT, Pacheco FAC. Influência de diferentes concentrações de flúor na água em indicadores epidemiológicos de saúde/doença bucal. Ciênc Saúde Colet. 2011;16(8):3509-18. doi: 10.1590/S141381232011000900019 addition to frequent on-site monitoring visits and, especially, implementation of health education programs in order to change the current scenario, warning letters should be issued or, in more serious violations, monetary penalties should be imposed.

The results of this study suggest the adoption of control measures and careful monitoring of mineral waters by the Health Surveillance agency, as well as social participation in the inspection of water fluoridation, especially commercial bottled waters.

\section{Collaborators}

DO BIZERRIL, JRS ALMEIDA, and MEL ALMEIDA contributed equally to all stages of conception and design of this study. KGH SALDANHA contributed to the search and organization of articles, manuscript writing, and critical revision. RE CABRAL FILHO contributed to data gathering, analysis, and interpretation and to manuscript writing.

7. Grec RHC, Moura PG, Ramires I, Lauris JRP, Buzalaf MAR. Consumo de água mineral em Bauru. In: 16 Jornada Odontológica de Bauru. 2003; Bauru. São Paulo. 2003.

8. Toumba KJ, Levy S, Curson MEJ. The fluoride content of bottled drinking waters. Br Dent J. 1994;176(7):226-8. doi: 10.1038/ sj.bdj. 4808431

9. Villena RS, Borges DG, Cury JA. Avaliação da concentração de flúor em águas minerais comercializadas no Brasil. Rev Saude Publica. 1996;30(6):512-18. doi: 10.1590/S003489101996000600004

10. Brasil. Ministério da Saúde (MS). Agência Nacional de Vigilância Sanitária. Resolução RDC n. 54, de 15 de junho de 2000. Dispõe sobre o Regulamento Técnico para Fixação de Identidade e Qualidade de Água Mineral Natural e Água Natural. [online] 2000 [citado 2013 maio 15]. Disponível em: <http://www. anvisa.gov.br/legis/resol/2000/54_00rdc.htm>.

11. Lindemeyer RG. Fluoride: surprising factors in bottled waters. Penn Dental J. 1996;63(1):13-7.

12. Tate $\mathrm{WH}, \mathrm{Chan} \mathrm{JT}$. Fluoride concentrations in bottled and filtered waters. Gen Dent. 1994;42:362-6.

13. Winkle SV, Levy SM, Kiritsy MC, Heilman JR, Wefel JS, Marshall T. Water and formula fluoride concentrations: significance for infants fed formula. Pediatr Deny. 1995;17:305-10.

14. Ramires I, Grec RHC, Cattan L, Moura PG, Lauris JRP, Buzalaf MAR. Avaliação da concentração de flúor e do consumo de água mineral. Rev Saude Publica. 2004;38(3):459-65. doi: $10.1590 /$ S0034-89102004000300018

15. Grec RHC, Moura PG, Pessan JP, Ramires I, Costa B, Buzalaf MAR. Concentração de flúor em águas engarrafadas comercializadas no município de São Paulo. Rev Saúde Pública. 2008;42(1):154-7. 
16. Catani DB, Amaral RC, Oliveira C, Sousa MLR, Cury JA. Dez anos de acompanhamento do heterocontrole da fluoretação da água feito por municípios brasileiros, Brasil, 1996-2006. RGO, Rev Gaúch Odontol. 2008;56(2):151-5.

17. Sayed N, Ditterich RG, Pinto MHB, Wambier DS. Fluoride concentration in bottled mineral water commercialized in the municipality of Ponta Grossa-PR. Rev Odontol UNESP. 2011;40(4):182-186.

18. Carvalho RV, Lund RG, Pino FAB, Demarco FF. Avaliação do teor de flúor em 14 áquas minerais comercializadas no município de Pelotas - RS. Rev Ibero-Am Odontopediatr Odontol Bebê. 2005;8(44):400-6.

19. Franco FC, Maltz MA. A concentração de fluoretos em águas minerais, chás brasileiros e chimarão. In: Anais da Reunião da Sociedade Brasileira de Pesquisa Odontológica; 1991; Águas de São Pedro. São Paulo: 1991
20. Ferreira RGLA, Marques RAA, Menezes LMB, Narvai PC. Múltiplos aspectos do uso do flúor em saúde pública na visão de lideranças da área de saúde. Ciênc Saúde Colet. 2013;18(7):2139-2146. doi: 10.1590/S1413-81232013000700029

Received on: 13/10/2014 Final version resubmitted on: 9/11/2014

Approved on:7/5/2015 